\title{
PENENTUAN JUMLAH PRODUKSI BAJU BATIK DI BATIK MERAK MANIS DENGAN METODE FUZZY MAMDANI
}

\author{
Dwi Rudi Setiawan ${ }^{1)}$; Kustanto ${ }^{2)}$; Yustina Retno Wahyu Utami ${ }^{3)}$ \\ 1,2,3) Program Studi Teknik Informatika, STMIK Sinar Nusantara \\ ${ }^{1)}$ setiawan836@gmail.com; ${ }^{2}$ kustanto@sinus.ac.id; ${ }^{3)}$ yustina.retno@sinus.ac.id
}

\begin{abstract}
Determination of production is one of the important activities within a company because it affects the production process that requires careful calculation. At this stage, the problem will arise because of the uncertainty in the determination of production. Fuzzy logic is one method to analyze a system that contains uncertainty. In this research used the Mamdani method or known as MinMax method. The purpose of this research is to build the application of the determination of the number of batik clothes production using Fuzzy Mamdani method. The variables used there are 3 namely: demand, inventory, and production. Data collection method used observation method, interview and literature study. The method to design the application system is DFD (Data Flow Diagram), ERD (Entity Relationship Diagram). The proposed system is developed using MySQL and PHP. The result of this research is an application to calculate the production amount of batik clothes, especially in Batik Merak Manis. Based on the results of 20 sample data obtained level performance of $99.51 \%$.
\end{abstract}

Keywords: Fuzzy mamdani, Batik clothing products, Determination.

\section{PENDAHULUAN}

Penentuan produksi merupakan salah satu kegiatan penting di dalam suatu perusahaan karena mempengaruhi proses produksi sehingga memerlukan perhitungan yang matang. Pada tahap ini permasalahan akan timbul karena ada ketidakpastian dalam penentuan produksi karena dipengaruhi oleh banyak indikator sedangkan jika hanya mengandalkan manusia dalam penentuanya maka akan terjadi perbedaan dalam mengambil keputusan karena pengetahuan dan pengalaman seseorang dapat berbeda beda. Maka diperlukan sebuah sistem yang dapat membantu pekerjaan tersebut sehingga dapat mempermudah dalam pengambilan keputusan.

Logika fuzzy merupakan salah satu metode yang digunakan dalam sistem yang mengandung ketidakpastian. Pada penelitian ini digunakan metode mamdani atau dikenal dengan metode Min-Max. Masalah yang diangkat oleh penulis adalah tentang penentuan jumlah produksi baju batik dengan studi kasus yang penulis pilih adalah Batik Merak Manis. Di Batik Merak Manis indikator sebagai variabel yang digunakan untuk menentukan jumlah produksi adalah permintaan dan persediaan sebagai variabel input dan produksi sebagai variabel output.

\section{TINJAUAN PUSTAKA}

Penelitian tentangPenentuan Jumlah Produksi Roti di UD Mega Saputra Menggunakan Fuzzy Tsukamoto. Dari penelitian tersebut diperoleh hasil bahwa penentuan jumlah produksi roti dari 20 data uji diperoleh tingkat kesesuaian sebesar $50 \%$. perbedaan dengan penelitian yang penulis angkat adalah pada metode yang digunakan[1]. Jika pada penelitian ini menggunakan metode fuzzy tsukamoto sedangkan metode yang digunakan penulis adalah fuzzy mamdani. Persamaan dalam penelitian yang penulis angkat adalah masalah penelitianya yaitu masalah penentuan jumlah produksi.

Penelitian selanjutnya tentangFuzzy Inference System Metode Mamdani Dalam Penentuan Nilai Akhir Ujian Hafalan AI-Quran. Dari penelitian tersebut diperoleh hasil bahwa fuzzy inference system metode mamdani dapat diterapkan dalam penentuan nilai akhir ujian hafalan Al-Quran berdasarkan kelancaran hafalan dan tajwid dengan diperolehnya nilai akhir sebesar 67,5 keanggotaan dari domain himpunan bilangan fuzzy[2]. Perbedaan dengan penelitian yang penulis angkat adalah pada studi kasus yang dihadapi. Dan persamaan dengan penelitian yang penulis angkat adalah pada metode yang digunakan yaitu metode fuzzy mamdani. 
Penelitian selanjutnya tentang Fuzzy Mamdani Dalam Menentukan Tingkat Keberhasilan Dosen Mengajar. Dari penelitian tersebut diperoleh hasil bahwa logika fuzzy membantu dalam memberikan hasil yang tidak crisp dengna menggunakan kesamaran suatu nilai dan menunjukan bahwa adanya korelasi antara variabel dosen dengan variabel niali dalam menentukan keberhasilan dosen megajar[3]. Persamaan dengan penelitian yang penulis angkat adalah pada metode yang digunakan yaitu metode mamdani. Dan perbedaan dengan penelitian yang penulis angkat adalah pada masalah penelitian yang diselesaikan.

Penelitian selanjutnya tentang Penerapan Metode Fuzzy Mamdani Dalam Memprediksi Tingginya Pemakaian Listrik (Studi Kasus Kelurahan Abc). Dari penelitian tersebut diperoleh kesimpulan bahwa pengujian yang dilakukan dengan matlab berhasil menentukan besaran pemakaian listrik berdarkan hasil pengujian data uji dengan variabel luas rumah seluas 55Meter persegi , perlengkapan 2 unit dan tegangan 900 watt diperoleh hasil dengan nilai 59,8 yang nilai tersebut masuk dalam rentang nilai Rendah[4]. Perbedaan dengan peneltiaan penelitian yang penulis angkat adalah pada masalah penelitianya. Dan persamaan dengan penelitian yang penulis angkat adalah pada metode mamdani yang sama dengan penulis gunakan.

Penelitian selanjutnya tentang Implementasi Metode Fuzzy Mamdani untuk Menentukan Jenis Ikan Konsumsi Air Tawar Berdasarkan Karakteristik Lahan Budidaya Perikanan. Dari penelitian tersebut diperoleh hasil bahwa kondisi $\mathrm{pH}$ dan kandungan $\mathrm{O} 2$ tidak begitu berpengaruh kepada rekomendasi jenis ikan. Dan metode fuzzy mamdani bisa diterapkan untuk penyelesaian permasalahan perikanan. Hal ini berdasarkan hasil uji yang dilakukan dengan nilai parameter yaitu ketinggian $90 \mathrm{~cm}$, kedalaman $275 \mathrm{~cm}$, , suhu 23 derajat, $\mathrm{pH} 5$ derajat keasaman, kandungan oksigen 11ppm dan kadar gula 250ppm diperoleh bahwa untuk lahan tersebut berdasarkan perhitungan fuzzy mamdani ikan direkomendasikan adalah ikan Nila[5]. Perbedaan dengan penelitian yang penulis angkat adalah pada masalah penelitian dan persamaan dengan penelitian yang penulis angkat adalah pada metode yang digunakan yaitu metode fuzzy mamdani[5].

\section{METODE PENELITIAN}

Metode penelitian yang dilakukan dalam melakukan penelitiaan untuk mendapatkan data yang lengkap dan akurat dilakukan pengumpulan data dengan cara: wawancara, observasi dan studi pustaka sedangkan metode yang digunakan untuk teknik pengembangan sistem adalah Daur Hidup Pengembangan Sistem (System Development Life Cycle) dengan tahapan sebagai berikut:

\section{Analisa Sistem}

Untuk mengembangkan sistem ini dibutuhkan perangkat lunak (software) dan perangkat keras (hardware).Perangkat lunak yang digunakan terdiri dari teks editor, scripting language dan database. Sedangkan perangkat keras berupa komputer untuk menjalankan sistem.

\section{Desain Sistem}

Desain sistem meliputi perancangan struktur data dengan menggunakan UML (Unified Modeling Language). Perancangan interface sistem menggunakan Bahasa Web Programming PHP yang dibuat dengan upaya pemakai mudah mengerti (user friendly).

\section{Pembuatan Sistem}

Sistem dibangun dengan menggunakan bahasa pemrograman PHP serta menggunakan Sublime Text 3 sebagai kode editor, Apache sebagai Web Server, Mysql sebagai Database.

\section{Pengujian Sistem}

Pengujian Sistem dilakukan dengan menggunakan uji validasi dimana membanding hasil perhitungan yang dilakukan di lapangan dengan hasil perhitungan yang menerapkan metode fuzzy mamdani.

\section{Implementasi Hasil}

Pada Tahap ini program ditampilkan di komputer pada browser Google Chrome dengan kriteria program dapat digunakan dengan mudah dan dipahami oleh user. Pada tahap ini perlu ditegaskan mengenai pemakaian program pada calon user.

\section{HASIL DAN PEMBAHASAN}

Dalam pembuatan sistem penerapan metode fuzzy mamdani untuk penentuan jumlah produksi baju batik di batik merak manis dilakukan persiapan data serta perancangan sistem guna memperjelas pembahasan yaitu 
Diagram Konteks, Entity Relationship Diagram, implementasi, dan pengujian validitas sistem.

\subsection{Persiapan Data}

Pada tahap ini menyiapkan data permintaan dan data persediaan serta data penentuan produksi berupa nilai maksimal dan minimal dari masing-masing variabel sebagai batas nilai domain dan kesemuanya diperlukan untuk mendapatkan hasil penentuan jumlah produksi baju batik.

\subsection{Penentuan Jumlah Produksi}

Batik Merak Manis memiliki sumber daya yang mampu memproduksi baju batik hingga 240 buah baju batik dalam satu kali produksi setiap minggunya. Tetapi untuk efisiensi sumber daya yang diharapkan Batik Merak Manis paling tidak memproduksi minimal 140 buah baju batim dalam satu kali produksi per minggunya. Masalah yang dihadapi Batik Merak Manis adalah tidak tentunya permintaan baju batik yang bervariasi antara 14 sampai 105 setiap minggu nya. Adapun tempat penyimpanan juga harus dibatasi yaitu paling tidak maksimal 140 buah baju batik dan persediaan minimal diharapkan tidak kurang dari 70 buah baju batik. Pada hari tertentu Batik Merak Manis memperoleh permintaan sebanyak 40 buah baju batik dan persediaan di gudang saat itu 100 buah baju batik. Hitunglah dengan menggunakan metode Fuzzy Mamdani berapa buah baju batik yang harus diproduksi pada minggu itu.

\section{* Fuzzifikasi}

Perhitungan fuzzifikasi atau pembentukan himpunan fuzzy untuk himpunan fuzzy Naik pada variabel permintaan dan himpunan fuzzy Banyak pada variabel persediaan merujuk pada rumus. Untuk himpunan fuzzy Turun pada variabel permintaan dan himpunan fuzzy sebagai berikut:

1. Permintaan

Fuzzifikasi atau pembentukan himpunan fuzzy Naik dan Turun pada variabel permintaan seperti pada Gambar 1.

$$
\mu(x)
$$

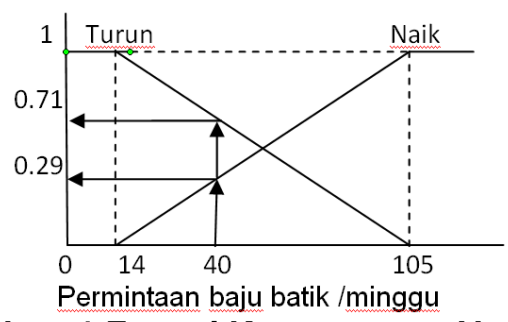

Gambar 1 Fungsi Keanggotaan Variabel Permintaan

$$
\begin{aligned}
& \mu \text { Naik }=\frac{x-\text { Min }}{\text { Max }- \text { Min }}=\frac{40-14}{105-14}=0.286 \\
& \mu \text { Turun }=\frac{\text { Max }-x}{\text { Max }- \text { Min }}=\frac{105-40}{105-14}=0.714
\end{aligned}
$$

2. Persediaan

Fuzzifikasi atau pembentukan himpunan fuzzy Sedikit dan Banyak pada variabel permintaan seperti pada Gambar 2.

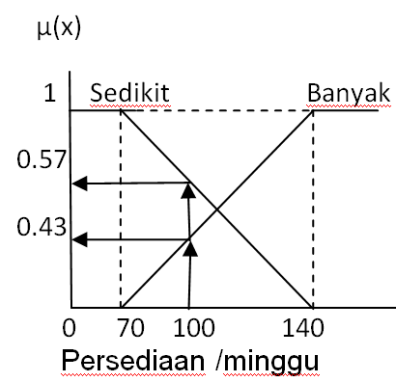

\section{Gambar 2 Fungsi Keanggotaan Variabel Persediaan}

$$
\begin{gathered}
\mu \text { Banyak }=\frac{x-\text { Min }}{\text { Max }- \text { Min }}=\frac{100-70}{140-70}=0.429 \\
\mu \text { Sedikit }=\frac{\text { Max }-x}{\operatorname{Max}-\operatorname{Min}}=\frac{140-100}{140-70}=0.571
\end{gathered}
$$

* Aplikasi Fungsi Implikasi

Aplikasi fungsi implikasi terdiri dari fungsi aplikasi yaitu yang digunakan adalah Min kemudian aturan fuzzy yang merujuk pada aturan bentuk umum fungsi implikasi dan Operasi fungsi implikasi.

Penentuan produksi memiliki 4 aturan:

[R1] IF Permintaan Turun AND Persediaan

Banyak THEN Produksi Berkurang.

[R2] IF Permintaan Turun AND Persediaan

Sedikit THEN Produksi Berkurang.

[R3] IF Permintaan Naik AND Persediaan

Banyak THEN Produksi Bertambah. 
[R4] IF Permintaan Naik AND Persediaan Sedikit THEN Produksi Bertambah.

- [R1] IF Permintaan TURUN And Persediaan BANYAK THEN Produksi BERKURANG;

a-predikat ${ }_{1}$

$$
\begin{aligned}
& =\mu_{\text {Pmt tu }} \cap \mu_{\text {Psd ba }} \\
& =\operatorname{Min}(0.714 ; 0.429) \\
& =0.429
\end{aligned}
$$

- [R2] IF Permintaan TURUN And Persediaan SEDIKIT THEN Produksi BERKURANG; a-predikat 2

$$
\begin{aligned}
& =\mu_{\text {Pmt_tu }} \cap \mu_{\text {Psd_sd }} \\
& =\operatorname{Min}(0.714 ; 0.571) \\
& =0.571
\end{aligned}
$$

- [R3] IF Permintaan NAIK And Persediaan BANYAK THEN Produksi BERTAMBAH; a-predikat ${ }_{3}$

$$
\begin{aligned}
& =\mu_{\text {Pmt_na }} \cap \mu_{\text {Psd_ba }} \\
& =\operatorname{Min}(0.286 ; 0.429) \\
& =0.286
\end{aligned}
$$

- [R4] IF Permintaan NAIK And Persediaan SEDIKIT THEN Produksi BERTAMBAH; a-predikat 4

$$
\begin{aligned}
& =\mu_{\text {Pmt } n a} \cap \mu_{\text {Psd_sd }} \\
& =\operatorname{Min}(0.286 ; 0.571) \\
& =0.286
\end{aligned}
$$

* Komposisi Aturan

Berdasarkan hasil fungsi implikasi dari tiap aturan, digunakan metode MAX untuk melakukan komposisi antar semua aturan. Proses penggabungan fungsi keanggotaan dengan menggunakan Metode Max dilakukan dengan menggunakan perumusan:

$$
\mu_{\mathrm{sf}}\left(\mathrm{x}_{\mathrm{i}}\right)=\max \left\{\mu_{\mathrm{sf}}\left(\mathrm{x}_{\mathrm{i}}\right), \mathrm{x}_{\mathrm{kf}}\left(\mathrm{x}_{\mathrm{i}}\right)\right\}
$$

dengan $\boldsymbol{\mu}_{\mathrm{sf}}\left(\mathbf{x}_{\mathbf{i}}\right) \quad \mathrm{m}$ enyatakan nilai keanggotaan solusi fuzzy sampai aturan ke$i, \mu_{s f}\left(x_{i}\right)$ menyatakan nilai keanggotaan konsekuensi fuzzy aturan ke- i. Tahap selanjutnya yaitu menentukan komposisi aturannya.

$$
\begin{aligned}
& \mu_{\mathrm{sf}}(\mathrm{x})=\max \left\{\mu_{\text {sedikit }}(\mathrm{x}), \mu_{\text {naik }}(\mathrm{x})\right\} \\
& \mu_{\mathrm{sf}}(\mathrm{x})=\max \{0.571,0.286\}
\end{aligned}
$$

Kemudian daerah hasil dibagi menjadi 3 bagian, yaitu A1, A2 dan A3. Kemudian mencari nilai a1 dan a2 dimana a1 merupakan batas antara daerah hasil $\mathrm{A} 1$ dan $\mathrm{A} 2$ dan a2 merupakan batas daerah hasil A2 dan A3.

Pada saat $\mu_{\text {naik }}\left(z_{1}\right)=0.286$, nilai $z_{1}$ dapat ditentukan sebagai berikut:

$$
\begin{aligned}
\alpha_{1} & \frac{\alpha_{1}-140}{240-140}=0.286 \\
& \alpha_{1}=(140+(0.286(240-140))) \\
& \alpha_{1}=168.6
\end{aligned}
$$

Pada saat $\mu_{\text {sedikit }}\left(z_{2}\right)=0.571$, nilai $z_{2}$ dapat ditentukan sebagai berikut:

$$
\begin{gathered}
\alpha_{2} \frac{\alpha_{2}-140}{240-140}=0.571 \\
\alpha_{2}=(140+(0.571(240-140))) \\
\alpha_{2}=197.1
\end{gathered}
$$

\section{* Defuzzifikasi}

Metode penegasan yang akan digunakan adalah metode centroidyang merujuk pada rumus (6). Untuk itu, pertama-tama kita hitung momen untuk setiap daerah yang telah dibagi pada tahap komposisi aturan. Proses dalam menentukan titik pusat daerah fuzzy dilakukan dengan menggunakan perumusan:

$$
Z^{*}=\frac{\int_{z} \mu(z) z d z}{\int_{z} \mu(z) z d z}
$$

dengan $Z^{*}$ menyatakan nilai hasil defuzzifikasi /titik pusat daerah fuzzy, $\mu(z)$ menyatakan nilai keanggotaan, dan $\int_{z} \mu(z) z$ $\mathrm{dz}$ menyatakan momen untuk semua daerah hasil komposisi aturan. Proses penentuan momen untuk setiap daerah. Untuk Momen 1,2 dan 3 adalah sebagai berikut:

$$
\begin{aligned}
\text { M1 } & =\int_{0}^{168.6}(0.286) z d z=0.143 z^{2} \int_{0}^{168.6}=4064.912 \\
& =\int_{168.6}^{197.1} \frac{(z-140)}{(240-140)} z d z \\
& =\int_{168.6}^{197.1}\left(z^{2}-14 z\right) d z=0.333 z^{3}-7 z^{2} \int_{190}^{197.1}=2252.30085 \\
\text { M3 } & =\int_{197.1}^{1240}(0.571) z d z=0.285 z^{2} \int_{197.1}^{240}=5353.57
\end{aligned}
$$

Kemudian dihitung luas setiap daerah $(A)$ yaitu A1, A2 \& A3 sebagai berikut:

$\mathrm{A} 1=168.6 * 0.286=48.2196$

$\mathrm{A} 2=(0.286+0.571) *(197.1-168.6) / 2=12.21225$

$A 3=(240-197.1) * 0.571=24.4959$ 
Berdasarkan perhitungan tersebut diperoleh titik pusat dari daerah fuzzy yaitu :

$z=\frac{4064.912+2252.30085+5353.57}{48.2196+12.21225+24.4959}=137.4202$

Hasil nilai " $z$ " kemudian dapat dibulatkan, sehingga didapat hasil penentuan jumlah produksi baju batik sebanyak 137.

\subsection{Diagram Konteks}

Diagram Konteks adalah diagram yang terdiri dari suatu proses dan menggambarkan ruang lingkup sistem. Diagram Konteks merupakan level tertinggi dari Data Flow Diagram yang menggambarkan seluruh input ke dalam sistem atau output dari sistem yang memberi gambaran tentang keseluruhan sistem.

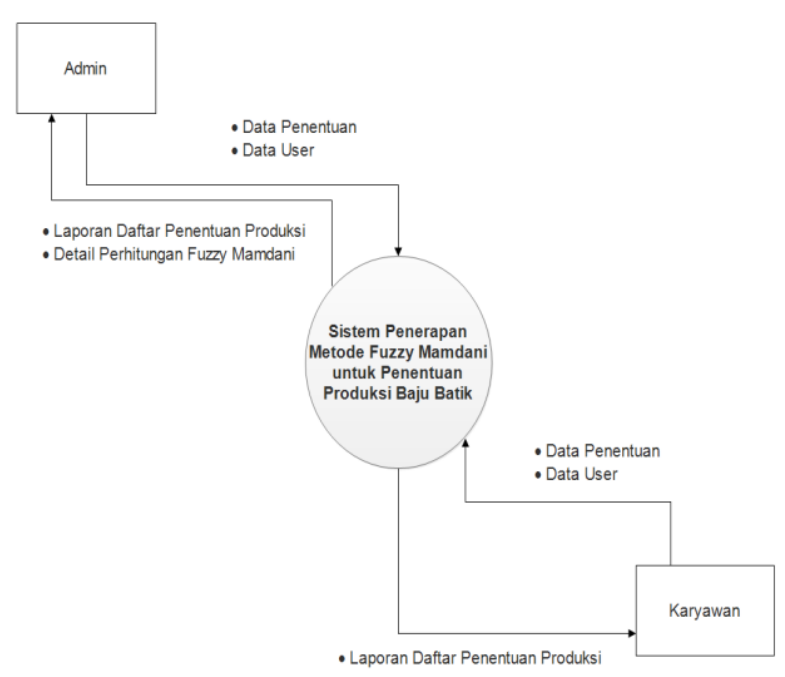

Gambar 3. Diagram Konteks

\subsection{Entity Relationship Diagram}

ERD (Entity Relationship Diagram) adalah suatu model untuk menjelaskan hubungan antar data dalam basis data berdasarkan objek-objek dasar data yang mempunyai hubungan antar relasi.ERD juga juga menggambarkan hubungan antara satu entitas dengan entitas yang memiliki jumlah atribut dengan entitas yang lain dalam suatu sistem yang terintregasi. Untuk menggambarkanya digunakan beberapa notasi dan simbol.

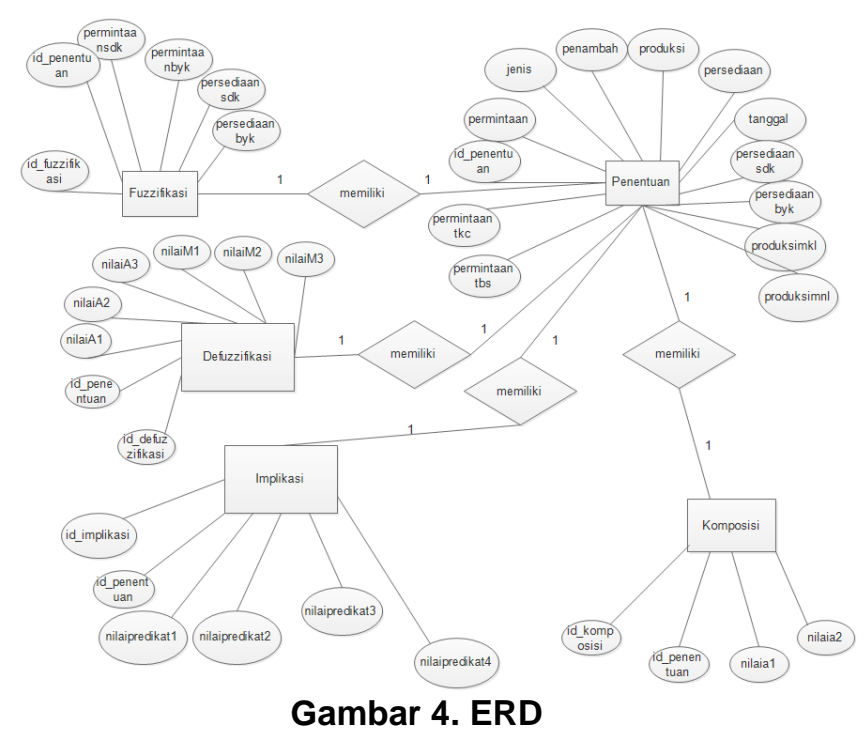

4.5 Implementasi

1. Halaman Input Penentuan Produksi

Halaman ini digunakan untuk input data penentuan produksi baju batik. Dimana user dapat menginputkan data maksimal dan minimal dari data penentuan produksi dan data testing yang terdiri dari jumlah persediaan saat ini dan jumlah permintaan yang diinginkan.

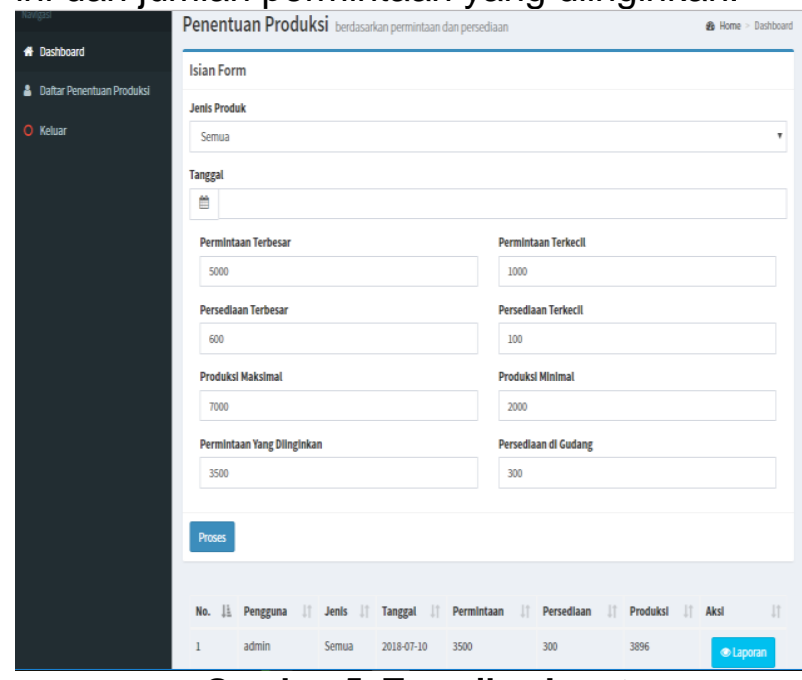

Gambar 5. Tampilan Input

2. Halaman Daftar Penentuan Produksi

Halaman ini digunakan untuk melihat keseluruhan data yang telah diproses sebelumnya. 


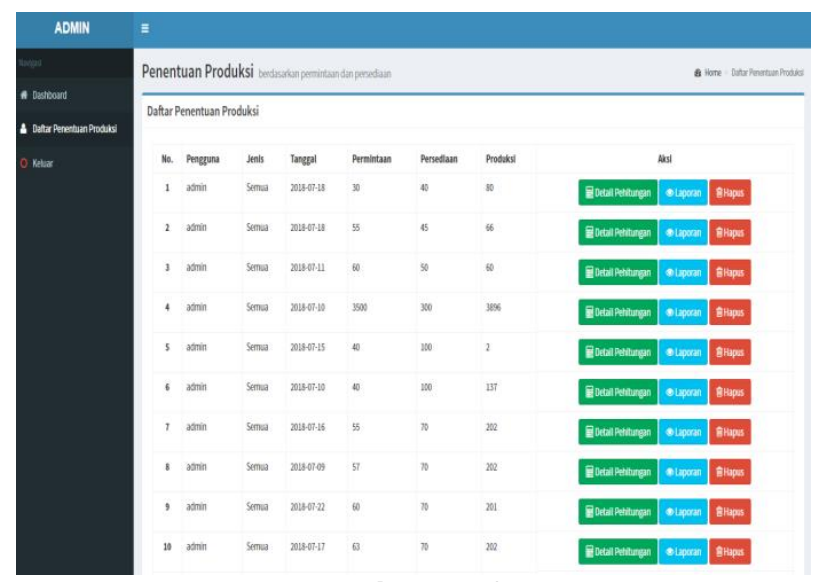

Gambar 6. Tampilan Daftar Penentuan

3. Halaman Laporan Penentuan Produksi

Halaman ini merupakan kelanjutan dari halaman daftar penentuan ketika pengguna klik tombol "laporan".
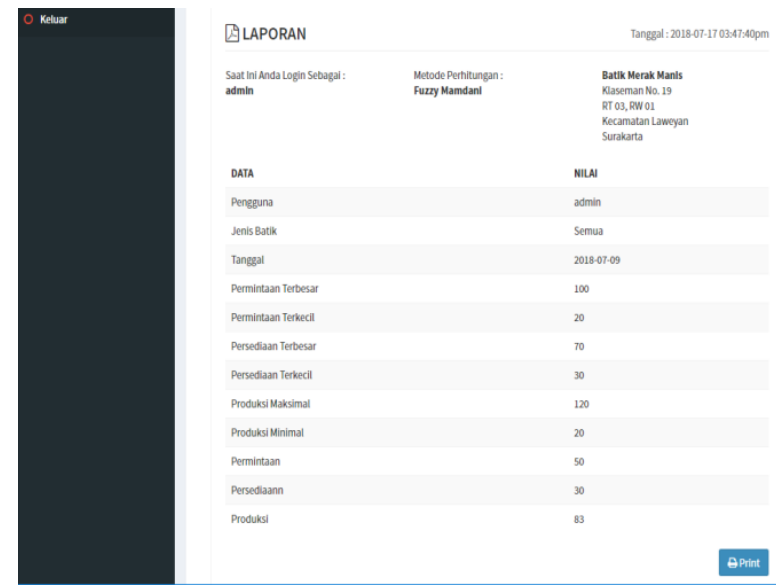

Gambar 7. Tampilan Laporan Penentuan

4. Halaman Detail Perhitungan

Halaman ini merupakan kelanjutan dari halaman daftar penentuan ketika pengguna klik tombol "detail perhitungan".

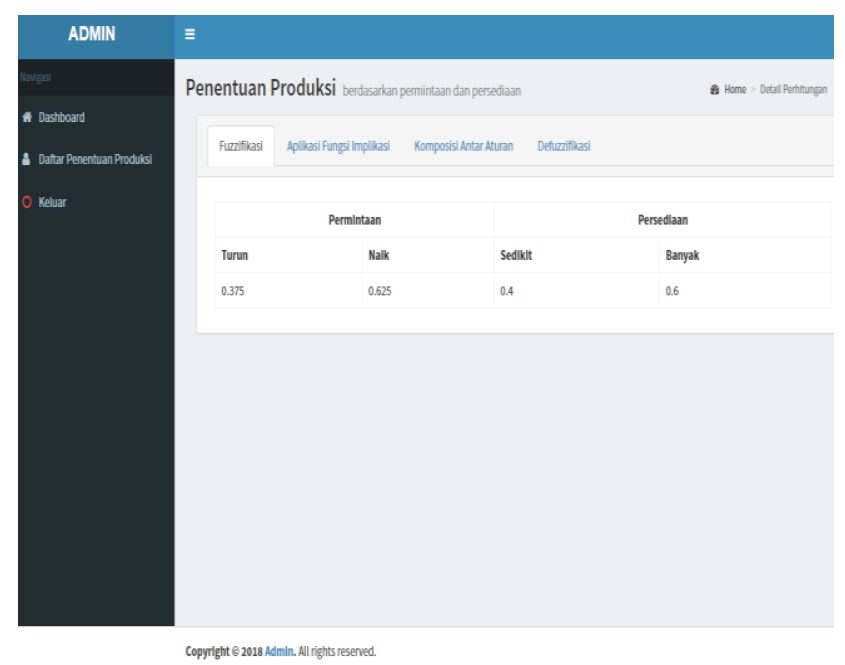

Gambar 8. Tampilan Detail Perhitungan

\subsection{Pengujian Validitas}

Uji validitas menggunakan metode Mean Absolute Percentage Error (MAPE). Pengujian validitas menggunakan 20 data uji menggunakan data penentuan produksi sebagai batas nilai domain. Tabel data penentuan produksi disajikan pada Tabel 1 dan adapun tabel perhitungan MAPE dapat dilihat pada Tabel 2.

\section{Tabel 1. Data Penentuan Produksi}

\begin{tabular}{|l|c|c|}
\hline No & Data & Jumlah \\
\hline 1 & Permintaan Terbesar & 105 \\
\hline 2 & Permintaan Terkecil & 14 \\
\hline 3 & Persediaan Terbesar & 140 \\
\hline 4 & Persediaan Terkecil & 70 \\
\hline 5 & Produksi Terbesar & 240 \\
\hline 6 & Produksi Terkecil & 140 \\
\hline
\end{tabular}

Tabel 2. Tabel Perhitungan MAPE

\begin{tabular}{|c|c|c|c|c|c|c|}
\hline $\begin{array}{r}\text { No } \\
\text { (t) }\end{array}$ & $\begin{array}{l}\text { Per } \\
\text { mint } \\
\text { aan }\end{array}$ & $\begin{array}{c}\text { Pers } \\
\text { edia } \\
\text { an }\end{array}$ & $\begin{array}{l}\text { Perhit } \\
\text { ungan } \\
\text { di } \\
\text { Lapan } \\
\text { gan } \\
\text { (ft) }\end{array}$ & $\begin{array}{c}\text { Perhitu } \\
\text { ngan } \\
\text { dengan } \\
\text { Metode } \\
\text { Fuzzy } \\
\text { Mamda } \\
\text { ni (xt) }\end{array}$ & $\begin{array}{c}\mid f t \\
- \\
x t \mid\end{array}$ & $|\mathrm{ft}-\mathrm{xt}| / \mathrm{ft}$ \\
\hline 1 & 40 & 100 & 140 & 137 & 3 & 0,0214 \\
\hline 2 & 37 & 86 & 150 & 150 & 0 & 0,0000 \\
\hline 3 & 80 & 70 & 205 & 205 & 0 & 0,0000 \\
\hline 4 & 100 & 90 & 185 & 185 & 0 & 0,0000 \\
\hline 5 & 80 & 125 & 150 & 152 & 2 & 0,0133 \\
\hline 6 & 70 & 90 & 140 & 139 & 1 & 0,0071 \\
\hline 7 & 70 & 130 & 160 & 160 & 0 & 0,0000 \\
\hline 8 & 35 & 100 & 145 & 144 & 1 & 0,0069 \\
\hline 9 & 25 & 85 & 170 & 170 & 0 & 0,0000 \\
\hline 10 & 35 & 70 & 205 & 205 & 0 & 0,0000 \\
\hline 11 & 65 & 100 & 130 & 126 & 4 & 0,0308 \\
\hline 12 & 70 & 78 & 170 & 167 & 3 & 0,0176 \\
\hline 13 & 80 & 70 & 205 & 205 & 0 & 0,0000 \\
\hline 14 & 37 & 78 & 170 & 170 & 0 & 0,0000 \\
\hline 15 & 51 & 92 & 135 & 135 & 0 & 0,0000 \\
\hline 16 & 39 & 70 & 205 & 205 & 0 & 0,0000 \\
\hline 17 & 38 & 86 & 150 & 150 & 0 & 0,0000 \\
\hline 18 & 39 & 78 & 170 & 170 & 0 & 0,0000 \\
\hline 19 & 58 & 90 & 135 & 135 & 0 & 0,0000 \\
\hline 20 & 67 & 104 & 125 & 125 & 0 & 0,0000 \\
\hline \multicolumn{6}{|c|}{ Jumlah } & 0,0972 \\
\hline
\end{tabular}

Dari Tabel 2 diatas, dapat dihitung persentase tingkat error sistem menggunakan MAPE.

$$
\begin{aligned}
\text { MAPE } & =\frac{\left(\sum_{t=1}^{n} \frac{|f t-x t|}{f t}\right) \times 100 \%}{n} . \\
& =\frac{0,0972 \times 100 \%}{20} \\
& =0,49 \%
\end{aligned}
$$

Berdasarkan hasil pengujian validitas yang dilakukan sebanyak 20 kali penguijian, didapat tingkat persentase error sebesar $0,49 \%$ atau 
tingkat akurasinya sebesar 99,51\%. Persentase yang didapat berdasarkan 20 data uji ini tidak dapat menjadikan tolok ukur jika data penentuan produksi pada Tabel 1 berubah.

\section{PENUTUP}

\subsection{Kesimpulan}

Berdasarkan pembahasan mengenai penerapanmetode Fuzzy Mamdani untuk menentukan jumlah produksi baju batik di Batik Merak Manis dapat ditarik kesimpulan sebagai berikut:

1. Dari kasus yang ada di Batik Merak Manis bisa diketahui bagaimana menerapkan metode fuzzy mamdani untuk menentukan jumlah produksi baju batik yaitu dengan melalui 4 langkah. Pertama menentukan himpunan fuzzy, kedua aplikasi fungsi implikasi, ketiga komposisi aturan, dan keempat defuzzifikasi.

2. Pembangunan program penerpan metode fuzzy mamdani untuk penentuan jumlah produksi baju batik di Batik Merak Manis dimulai dengan melakukan perancangan sistem dengan menggunakan Data Flow Diagram, kemudian dilanjutkan dengan desain interface, kemudian desain database, selanjutnya pada kontruksi sistem menggunakan bahasa pemrograman PHP dengan Sublime Text sebagai editor kemudian program di tes menggunakan browser Google Chrome.

3. Hasil perhitungan dengan menerapkan metode fuzzy mamdani untuk penentuan jumlah produksi baju batik di Batik Merak Manis didapat persentase tingkat akurasi sebesar $99,51 \%$.

\subsection{Saran}

Berdasarkan simpulan hasil penelitian, saran yang perlu disampaikan adalah sebagai berikut.

1. Pada penelitian ini digunakan 3 variabel dalam menetukan jumlah produksi yaitu permintaan dan persediaan sebagai variabel input dan produksi sebagai variabel output. Untuk penelitian selanjutnya variabel lain dapat ditambahkan sehingga banyak kemungkinan yang bisa menjadi pertimbangan untuk menentukan hasil output.

2. Pada penelitian ini Batik Merak Manis menggunakan analisis ekonomis dalam menentukan nilai maksimal dan minimal dari data produksi akan tetapi dalam penelitian ini tidak dibahas terkait bagaimana analisis ekonomis dalam menentukan nilai maksimal dan minimal dari data produksi. Untuk penelitian selanjutnya diharapkan dibahas mengenai analisis dalam menentukan nilai maksimal dan minimal dari data produksi.

3. Pada penelitian ini tidak ada variabel input yang dominan dalam menentukan output penentuan jumlah produksi sehingga semua variabel mempunyai pengaruh yang sama terhadap output penentuan jumlah produksi. Untuk peneltian selanjutnya terdapat input bersifat dominan yang berpengaruh terhadap output.

\section{DAFTAR PUSTAKA}

[1] K. M. Herdiastuti, B. Widada and Y. R. W. Utami, "Implementasi Algoritma Fuzzy Tsukamoto untuk Menentukan Jumlah Produksi Roti," Jurnal TIKomSiN, 2016.

[2] K. Hati, "Fuzzy Inference System Metode Mamdani Dalam Penentuan Nilai Akhir Ujian Hafalan Al-Qur'an," BINA INSANI ICT JOURNAL, 2016.

[3] S. R. Andani, "Fuzzy Mamdani Dalam Menentukan Tingkat Keberhasilan Dosen Mengajar," Seminar Nasional Informatika, 2013.

[4] E. V. Haryanto and F. Nasari, "Penerapan Metode Fuzzy Mamdani Dalam Memprediksi Tingginya Pemakaian Listrik (Studi Kasus Kelurahan ABC)," Seminar Nasional Teknologi Informasi dan Multimedia, 2015.

[5] A. Wirawan and A. , "Implementasi Metode Fuzzy Mamdani untuk Menentukan Jenis Ikan Konsumsi Air Tawar Berdasarkan Karakteristik Lahan Budidaya Perikanan," Jurnal Berkala MIPA, 24(1), 2014. 